\title{
PENDUGAAN BIOMASSA DAN KANDUNGAN KARBON KAYU AFRIKA (Maesopsis emenii Engl.) DI KABUPATEN SUKABUMI, JAWA BARAT
}

\author{
Biomass and Carbon Stock of Maesopsis emenii Engl. at Sukabumi District, West Java \\ Ismayadi Samsoedin ${ }^{1}$, Harmastini Sukiman ${ }^{2}$, Marfuah Wardani ${ }^{1}$ dan/and N. M. Heriyanto ${ }^{1}$ \\ 'Pusat Penelitian dan Pengembangan Hutan \\ Jl. Gunung Batu Kotak Pos 165 Telp. (0251) 8633234, 7520067 \\ Fax. (0251) 8638111 Bogor, Jawa Barat, Indonesia \\ ${ }^{2}$ Pusat Penelitian Bioteknologi LIPI. \\ Jl. Raya Bogor KM 46, Cibinong, Bogor, Jawa Barat, 16911; \\ Telp. (021) 8754587, 87905152; Fax (021) 8754588 \\ E-mail: isamsoedin@gmail.com; p2biotek@bioteknologi.lipi.go.id; marfuah58@yahoo.co.id; \\ nurmheriyanto88@yahoo.com
}

Tanggal diterima: 19 Januari 2015; Tanggal direvisi: 25 Mei 2016; Tanggal disetujui:

\begin{abstract}
Maesopsis emenii Engl. is one of the fast growing species that can grow on marginal soils with a high enough increment. This study aims to develop allometry equation and predict carbon content in every part of tree and forest stands of $\underline{\mathrm{M}}$. emenii at the age of eight years. Data was collected using a destructive sampling method through selection of sample trees, 10 out of 450 trees were selected that best represent the stand. Results showed that dry weight of the average oven plant organs are, consecutively stem sections $122.54 \mathrm{~kg}, 42.94 \mathrm{~kg}$ of roots, branches and twigs of $7.15 \mathrm{~kg}$ and $6.03 \mathrm{~kg}$ of leafs. Allometry equation between the above-ground dry weight of diameter is $Y=$ $0,0363 X^{2.5131}\left(R^{2}=0.96\right)$, logs with diameter of $Y=0,0347 X^{2.4926}\left(R^{2}=0.95\right)$, root with diameter of $Y=0,0205 X^{2.3267}(R$ $\left.{ }^{2}=0.90\right)$ and between total dry weight with diameter of $Y=0,0559 X^{2.464}\left(R^{2}=0.97\right)$. Carbon content obtained at the highest part of the trunk that is as much as $68,07 \%$, respectively roots as much as $23,87 \%$, branches and twigs of 3,97\% and the leaves as much as 3,35\%. Total carbon content in the stands at $\mathrm{M}$. emenii 30.65 tonnes Cper ha.
\end{abstract}

Keyword: Biomass, carbon content and Maesopsis emenii

\begin{abstract}
ABSTRAK
Kayu afrika (Maesopsis emenii Engl.) merupakan salah satu tanaman tumbuh cepat yang dapat tumbuh pada tanah marjinal dengan riap yang cukup tinggi. Penelitian ini bertujuan untuk membuat persamaan alometri guna menduga kandungan karbon di setiap bagian pohon dan menduga potensi karbon pada tegakan kayu afrika umur 8 tahun dan menduga kandungan karbon pada tegakan hutan tanaman kayu afrika (M. emenii) umur 8 tahun. Pengumpulan data dilakukan dengan menggunakan metode destructive sampling melalui pemilihan pohon contoh, dari 450 pohon dipilih 10 pohon yang dapat mewakili tegakan tersebut. Hasil penelitian menunjukkan bahwa berat kering oven ratarata bagian kayu afrika berturut-turut adalah bagian batang $122,54 \mathrm{~kg}$, akar $42,94 \mathrm{~kg}$, cabang dan ranting 7,15 kg dan bagian daun $6,03 \mathrm{~kg}$. Persamaan alometri antara berat kering bagian atas tanah kayu afrika dengan diameter ialah $Y=$ $0,0363 \mathrm{x}^{2,5131}\left(\mathrm{R}^{2}=0,96\right)$, batang kayu afrika dengan diameter ialah $\mathrm{Y}=0,0347 \mathrm{x}^{2,4926}\left(\mathrm{R}^{2}=0,95\right)$, akar kayu afrika dengan diameter ialah $Y=0,0205 \mathrm{x}^{2,3267}\left(\mathrm{R}^{2}=0,90\right)$ dan antara berat kering total kayu afrika dengan diameter ialah $\mathrm{Y}$ $=0,0559 \mathrm{x}^{2,464}\left(\mathrm{R}^{2}=0,97\right)$. Kandungan karbon kayu afrika paling tinggi diperoleh pada bagian batang sebanyak $68,07 \%$, berturut-turut bagian akar sebanyak $23,87 \%$, cabang dan ranting $3,97 \%$ dan bagian daun sebanyak $3,35 \%$. Total kandungan karbon pada tegakan kayu afrika umur 8 tahun sebesar 30,65 ton $\mathrm{C}$ per ha.
\end{abstract}

Kata kunci: Biomassa, kandungan karbon, Maesopsis emenii

\section{PENDAHULUAN}

Kayu Afrika (Maesopsis eminii Engl.) merupakan jenis tanaman kehutanan dari yang famili Rhamnaceae. Jenis ini tumbuh tersebar secara alami di daerah tropika Afrika Timur, dan diintroduksi pertama kali di daerah Jawa Barat tahun enam puluhan. Kayu afrika termasuk jenis tanaman eksotik dan cepat tumbuh (fast growing species). Tanaman kayu afrika termasuk jenis 
intoleran yaitu jenis yang membutuhkan cahaya penuh. Jenis ini mampu tumbuh baik pada ketinggian 100-900 m dari permukaan laut (dpl), curah hujan 1.000-2.000 mm per tahun, tekstur tanah ringan-sedang dan drainase baik (Pratiwi et al., 2014; Bintoro \& Riniarti, 2014).

Kegunaan kayunya luas, yaitu untuk kayu bahan bangunan seperti konstruksi ringan, peti kemas, box dan plywood (Pratiwi et al., 2014). Karakteritik kayu afrika memiliki gubal berwarna hampir putih dan kayu terasnya kekuningan apabila masih basah, berubah menjadi coklat keemasan atau coklat tua setelah lama terbuka. Tekstur kayu agak kasar dengan serat bersilang, menghasilkan corak pada permukaan papan. Kerapatan kayu pada kadar air 15\% sebesar 0,64$0,72 \mathrm{~g}$ per $\mathrm{cm}^{3}$ dari pohon berumur 42 tahun sedangkan dari pohon berumur 6 tahun sebesar $0,58-0,64 \mathrm{~g}$ per $\mathrm{cm}^{3}$ (Ani \& Aminah, 2006). Tanaman kayu afrika memiliki manfaat yang ganda mulai dari kayu, daun dan penyerap karbondioksida dari udara dan penghasil oksigen. Hasil dari fotosintesis tanaman tersebut akan disimpan di komponen pohon dalam bentuk biomassa baik yang hidup maupun yang sudah mati (Onrizal \& Kusmana, 2009).

Besar kecilnya biomassa tanaman ditentukan oleh umur tanaman, diameter, tinggi, kesuburan tanah dan sistem silvikultur yang diterapkan (Heriansyah et al., 2007; Dharmawan \& Siregar, 2008; Subiandono et al., 2013). Hal ini berakibat pada kemampuan tanaman untuk menyimpan karbon yang bervariasi. Biomassa hutan, kurang lebih sebanyak 45-50 persen adalah kandungan karbon (Onrizal et al., 2008; Bismark et al., 2008; Dharmawan \& Samsoedin, 2012). Samsoedin et al. (2009) menyatakan bahwa kandungan karbon di hutan primer Aek Nabara Batang Toru, Sumatera Utara sebesar 104,78 ton C per ha. Kandungan karbon di hutan tanaman Acacia mangium Wild. umur 5 tahun di Kabupaten Bogor, Jawa Barat sebesar 31,41 ton C per ha dan Pinus merkusii Jungh et De Vriese umur 5 tahun sebesar 11,93 ton C per ha (Heriyanto \& Siregar, 2007a; Heriyanto \& Siregar 2007b).

Data biomassa suatu ekosistem sangat berguna untuk mengevaluasi pola produktivitas berbagai macam ekosistem yang ada. Tegakan hutan tanaman mempunyai potensi besar dalam menyerap dan mengurangi kadar karbondioksida di udara melalui kegiatan konservasi dan perbaikan manajemen tegakan hutan tanaman. Oleh karena itu, kandungan karbon yang terdapat pada komponen pohon kayu afrika menjadi penting untuk diketahui. Data tersebut sangat bermanfaat guna menduga potensi karbon pada kerapatan tegakan dan umur tertentu. Penelitian kandungan karbon pada jenis dan umur tertentu belum banyak dilakukan, sehingga penelitian ini bertujuan untuk membuat persamaan alometri guna menduga kandungan karbon di setiap bagian pohon dan menduga potensi karbon pada tegakan kayu afrika umur 8 tahun.

\section{METODOLOGI}

\section{A. Lokasi dan Waktu Penelitian}

Penelitian ini dilakukan di kawasan hutan Bodogol, Seksi Konservasi Wilayah II Taman Nasional Gunung Gede Pangrango, Kabupaten Sukabumi, Jawa Barat. Lokasi ini mempunyai ketinggian tempat antara $600 \mathrm{~m}$ sampai $800 \mathrm{~m}$ dari permukaan laut (dpl), iklimnya termasuk tipe A dengan curah hujan rata-rata $4.962 \mathrm{~mm}$ per tahun menurut Schmidt \& Ferguson. Secara geografis lokasi penelitian terletak pada koordinat $106^{\circ} 51^{\prime} 17^{\prime \prime}$ Bujur Timur dan $6^{\circ} 46^{\prime} 38^{\prime \prime}$ Lintang Selatan.

Keadaan topografi Bodogol secara umum berbukit-bukit, dengan kemiringan lahan antara $25 \%$ sampai $60 \%$. Berdasarkan Peta Tanah Tinjau Pulau Jawa dan Madura. Tanah di lokasi penelitian termasuk jenis tanah Latosol. Penelitian dilakukan pada bulan Mei-Juni 2014.

\section{B. Bahan Penelitian}

Bahan penelitian adalah tegakan tanaman kayu Afrika (M. emenii) berumur 8 tahun dengan jarak tanam $2 \mathrm{~m} \times 3 \mathrm{~m}$, setelah penjarangan menjadi $4 \mathrm{~m}$ x $6 \mathrm{~m}$. Pada penelitian ini jumlah tanaman kayu afrika ada 450 pohon. Semua tanaman dalam plot diukur diameter dan tinggi. Selanjutnya data tersebut menjadi dasar dalam menentukan jumlah pohon contoh yang diambil.

\section{Metode Penelitian}

1. Pemilihan pohon contoh

Setelah dilakukan sensus pohon, pohon yang dipilih berdasarkan distribusi diameter (DBH) pada lokasi tersebut yaitu pohon dengan diameter terbesar dan terkecil yang menyebar merata. Untuk penelitian ini diperlukan 10 pohon contoh yang dapat mewakili tegakan tersebut.

2. Pengukuran tinggi dan diameter batang pohon Setelah pohon ditebang, diameter batang diukur berturut-turut pada posisi $0 \mathrm{~m} ; 0,3 \mathrm{~m}$; 1,3 m (DBH); 3,3 m; 5,3 m; 7,3 m; 9,3 m dan 
seterusnya setiap 2 meter. Selain itu juga diukur diameter bebas cabang (Dbc).

3. Pengukuran berat basah pohon

Cabang dan ranting dipisahkan dari batang dan batang dipotong dalam bentuk log, dimana masing-masing log diberi nomor dan ditimbang. Cabang dan ranting yang hidup kemudian dipisahkan dari cabang dan ranting mati. Daun juga dipisahkan dari cabang dan ranting.

4. Contoh dipilih dan ditimbang untuk diukur berat kering dan kandungan karbonnya. Pengambilan contoh bagian batang utama mulai bagian bawah sampai atas pohon, bagian batang yang diambil untuk contoh kandungan karbon yaitu bagian batang utama di atas tanah setinggi $0-0,3 \mathrm{~m} ; 0,3-1,3 \mathrm{~m} ; 1,3-$ 3,3 m; 3,3-5,3 m; 5,3-7,3 m dan seterusnya. Bagian akar, cabang dan ranting hidup, cabang dan ranting mati serta daun, masingmasing sebanyak kurang lebih 250 gram.

5. Untuk mengetahui berat kering, contoh dimasukkan dalam kantung kertas dan dikeringkan di oven pada suhu $85^{\circ} \mathrm{C}$ selama 48 jam.

\section{Analisis Data}

Untuk mengetahui berat kering contoh digunakan rumus sebagai berikut:

$\mathrm{Bkt}=\frac{\mathrm{Bks} \times \mathrm{Bbt}}{\mathrm{Bbs}}$

Dimana :

$\mathrm{Bkt}=$ Berat kering total $(\mathrm{kg})$,

$\mathrm{Bks}=$ Berat kering contoh (gr),
$\mathrm{Bbt}=$ Berat basah total $(\mathrm{kg})$,

$\mathrm{Bbs}=$ Berat basah contoh (gr).

- Kandungan karbon dalam tanaman dihitung dengan menggunakan rumus:

- Kandungan karbon= berat kering tumbuhan $\mathrm{x}$ kadar karbon

Kadar karbon pada pohon kayu afrika menurut (Hairiah \& Rahayu, 2007) adalah bagian batang $68 \%$, cabang dan ranting $4,7 \%$, akar $24 \%$, daun 3,3\% dan secara total $46 \%$.

- Serapan karbondioksoda $\left(\mathrm{CO}_{2}\right)=\mathrm{Mr} . \mathrm{CO}_{2} / \mathrm{Ar}$. $\mathrm{C}$ (atau 3,67 x kandungan karbon)

Keterangan : $\mathrm{Mr}$ : molekul relatif., Ar : Atom relatif.

- Pendugaan persamaan alometri dilakukan dengan menggunakan rumus:

Dimana :

$$
\mathrm{Y}=\mathrm{a} \mathrm{X}^{\mathrm{b}}
$$

$\mathrm{Y}=$ Berat kering pohon

$\mathrm{X}=$ Diameter pada tinggi $10 \mathrm{~cm}$ di atas leher akar

$\mathrm{a}, \mathrm{b}=$ Koefisien

Dalam penelitian ini juga dilakukan pengujian keabsahan dan keakuratan model.

\section{HASIL DAN PEMBAHASAN}

\section{A. Kelas Diameter dan Tinggi Pohon Contoh}

Empat ratus lima puluh pohon diambil pohon contoh sebanyak 10 pohon yang dapat mewakili tegakan tersebut. Kelas diameter dan tinggi ratarata pohon contoh disajikan pada Tabel 1 .

Tabel(Table) 1. Sebaran kelas diameter pohon contoh kayu afrika berumur 8 tahun (Class diameter distribution of 8 year old afrika wood sample tree)

\begin{tabular}{ccccc}
\hline No. & $\begin{array}{c}\text { Diameter setinggi dada } \\
\text { (Diameter at breast height }) \\
(\mathrm{cm})\end{array}$ & $\begin{array}{c}\text { Diameter bebas cabang } \\
(\text { Diameter at the lowest branch }) \\
(\mathrm{cm})\end{array}$ & $\begin{array}{c}\text { Tinggi bebas cabang } \\
(\text { Height of free } \\
\text { branch })(\mathrm{m})\end{array}$ & $\begin{array}{c}\text { Tinggi total } \\
(\text { Total height }) \\
(\mathrm{m})\end{array}$ \\
\hline 1. & 15,7 & 9,4 & 7,82 & 9,75 \\
2. & 20,2 & 12,0 & 11,32 & 13,54 \\
3. & 23,7 & 8,7 & 17,40 & 18,74 \\
4. & 22,2 & 8,7 & 13,35 & 14,76 \\
5. & 25,7 & 11,9 & 17,30 & 19,57 \\
6. & 26,1 & 12,0 & 17,31 & 19,34 \\
7. & 27,5 & 9,6 & 17,30 & 18,43 \\
8. & 30,1 & 9,7 & 15,32 & 17,32 \\
9. & 28,5 & 8,3 & 13.40 & 15,38 \\
10. & 36,3 & 5,5 & 15,30 & 17,36 \\
Rata-rata & 25,6 & 9,6 & 14,71 & 16,42 \\
(Average $)$ & & & & \\
STDEV & 5,67 & 2,0 & 3,17 & 3,09 \\
\hline
\end{tabular}


Pada Tabel 1 dapat dilihat bahwa tinggi bebas cabang rata-rata relatif tinggi yaitu $9,58 \mathrm{~m}$, hal ini dikarenakan tanaman kayu afrika termasuk jenis pohon yang tumbuh cepat (fast growing species), daur tebang untuk kelas perusahaan pulp dan kertas 6-8 tahun sedangkan untuk kayu pertukangan 10 tahun. Kerapatan tegakan pada umur 8 tahun 450 pohon per hektar.

\section{B. Biomassa Tegakan}

Biomassa tegakan dapat dibedakan ke dalam dua kategori, yaitu biomassa di atas tanah (batang, cabang, ranting, daun, bunga dan buah) dan biomassa di dalam tanah (akar). Diameter setinggi dada $(\mathrm{DBH})$ tanaman berkaitan erat dengan biomassa, dimana semakin besar diameter, maka semakin besar biomassanya. Data berat kering, yang merupakan penduga biomassa pohon contoh disajikan pada Tabel 2 .

Pada Tabel 2, biomassa daun, cabang ranting hidup atau mati tidak mengikuti kecenderungan besaran biomassa batang dan akar. Rata-rata biomassa pohon kayu afrika umur 8 tahun biomassa terbesar berada pada bagian batang $(122,454 \mathrm{~kg}$ atau $68,07 \%)$, diikuti oleh akar $(42,94 \mathrm{~kg}$ atau $23,87 \%)$, cabang dan ranting hidup $(7,149 \mathrm{~kg}$ atau $3,97 \%)$, daun $(6,029 \mathrm{~kg}$ atau $3,35 \%)$, cabang dan ranting mati $(1,317 \mathrm{~kg}$ atau $0,73 \%$ ). Secara umum biomassa pada tiap bagian pohon terbesar diperoleh dari pohon dengan diameter yang terbesar pula. Hal ini dapat dijelaskan bahwa biomassa berkaitan erat dengan proses fotosintesis. Hasil dari fotosintesis tersebut digunakan oleh tumbuhan untuk melakukan pertumbuhan baik ke arah vertikal (tinggi) maupun horizontal (diameter) dan sisanya disimpan dalam batang.

\section{A. Persamaan Alometri dan Kandungan Karbon Tegakan Kayu Afrika}

\section{Persamaan alometri}

Kandungan biomassa dari hutan tanaman dapat diestimasi secara langsung dengan menggunakan persamaan regresi biomassa, yaitu fungsi matematik yang didasarkan pada hubungan berat kering biomassa dengan satu atau lebih kombinasi dari dimensi tegakan pohon. Persamaan regresi yang digunakan didasarkan pada data dari tegakan yang diameternya dapat mewakili kisaran kelas diameter pada tegakan tersebut.

Pengukuran berat biomassa tanaman hutan yang dilakukan dengan cara menebang seluruh tanaman memerlukan waktu lama dan biaya yang besar. Untuk mempermudah diperlukan adanya persamaan alometri, yang berguna untuk menduga berat total biomassa tegakan. Setelah ditemukan alometri, maka berat biomassa tegakan dapat dihitung hanya dengan mengukur diameter. Model alometri biomassa untuk pohon kayu afrika berumur delapan tahun dapat dilihat pada Gambar 1-4.

Tabel (Table) 2. Berat kering biomassa pohon contoh kayu afrika berumur 8 tahun (Dry biomass of 8 year old afrika wood sample tree)

\begin{tabular}{|c|c|c|c|c|c|c|c|}
\hline \multirow[b]{2}{*}{ No. } & \multirow[b]{2}{*}{$\begin{array}{l}\text { Diameter } \\
(\mathrm{cm})\end{array}$} & \multicolumn{5}{|c|}{ Biomassa (Biomass) (kg) } & \multirow[b]{2}{*}{$\begin{array}{c}\text { Berat tota } \\
\text { (Total dry } \\
\text { weight) } \\
(\mathrm{kg})\end{array}$} \\
\hline & & $\begin{array}{l}\text { Daun } \\
\text { (Leave) }\end{array}$ & $\begin{array}{l}\text { Cabang dan } \\
\text { ranting hidup } \\
\text { (Branch and } \\
\text { twig live) }\end{array}$ & $\begin{array}{l}\text { Cabang and } \\
\text { ranting mati } \\
\text { (Branch and } \\
\text { twig dead) }\end{array}$ & $\begin{array}{l}\text { Batang } \\
(\text { Stem })\end{array}$ & $\begin{array}{l}\text { Akar } \\
(\text { Root })\end{array}$ & \\
\hline 1. & 15,7 & 0,97 & 2,27 & 0,96 & 30,37 & 14,46 & 49,03 \\
\hline 2. & 20,2 & 3,70 & 2,59 & 1,17 & 80,16 & 20,88 & 108,5 \\
\hline 3. & 22,2 & 1,84 & 2,24 & 0,82 & 84,53 & 30,03 & 119,46 \\
\hline 4. & 23,7 & 2,16 & 2,79 & 1,13 & 85,84 & 33,50 & 125,42 \\
\hline 5. & 25,7 & 4,45 & 4,99 & 1,24 & 104,45 & 37,25 & 152,38 \\
\hline 6. & 26,1 & 8,47 & 8,84 & 1,20 & 109,04 & 35,17 & 162,72 \\
\hline 7. & 27,5 & 7,13 & 11,90 & 2,42 & 113,54 & 43,61 & 178,6 \\
\hline 8. & 28,5 & 10,48 & 9,38 & 1,13 & 148,22 & 34,12 & 203,33 \\
\hline 9. & 30,1 & 12,05 & 9,09 & 1,35 & 188,30 & 67,93 & 278,72 \\
\hline 10. & 36,3 & 9,04 & 17,40 & 1,75 & 280,09 & 112,50 & 420,78 \\
\hline \multicolumn{2}{|c|}{ Rata-rata (Average) } & 6,03 & 7,15 & 1,32 & 122,45 & 42,94 & 179,89 \\
\hline STDEV & 5,67 & 3,92 & 5,07 & 0,46 & 69,51 & 28,26 & 104,48 \\
\hline
\end{tabular}




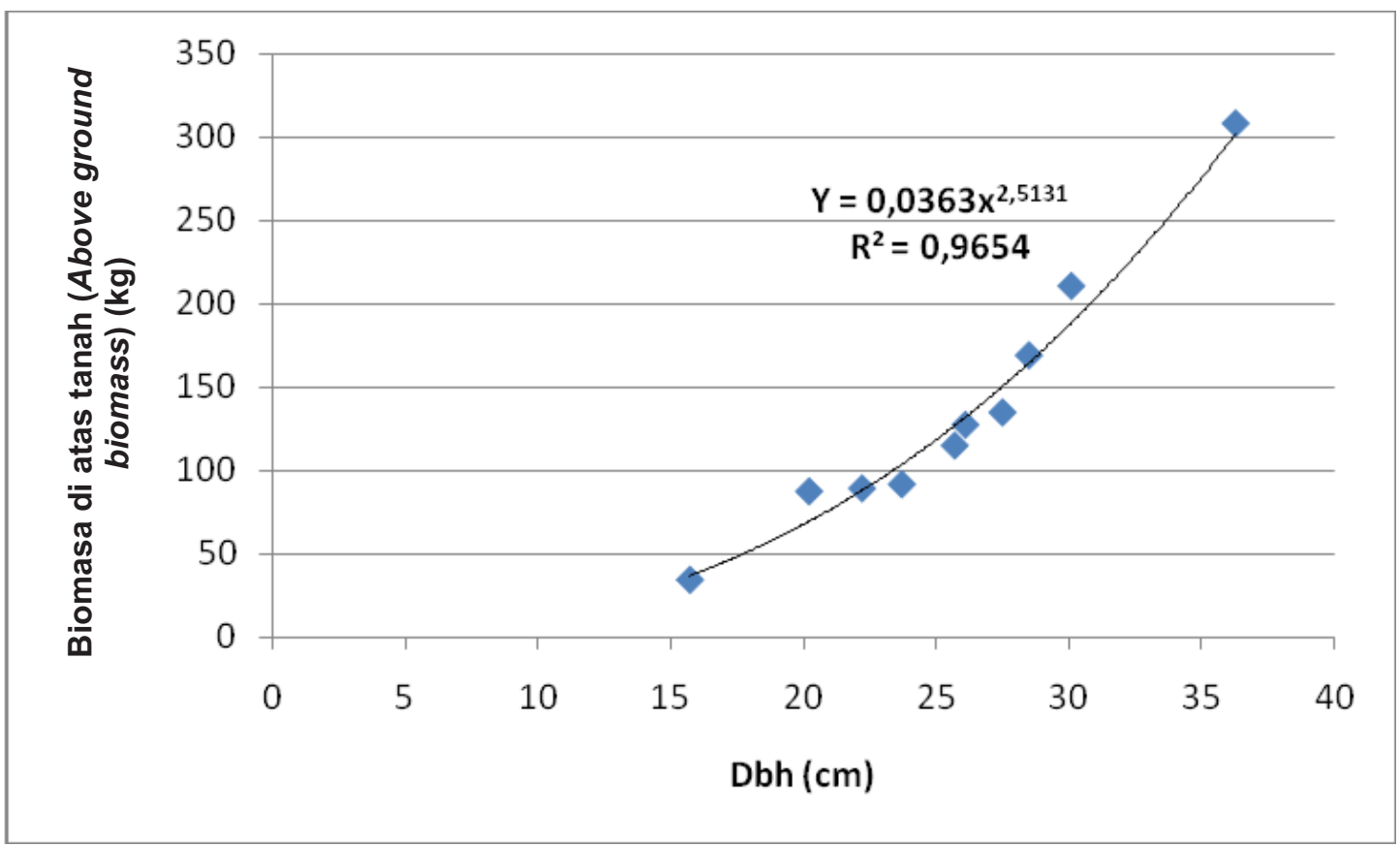

Gambar(Figure) 1. Grafik hubungan antara biomassa bagian atas tanah kayu afrika dengan diameter beserta persamaan alometrinya (Allometric equation of the relationship between above ground biomass and diameter at breast height)

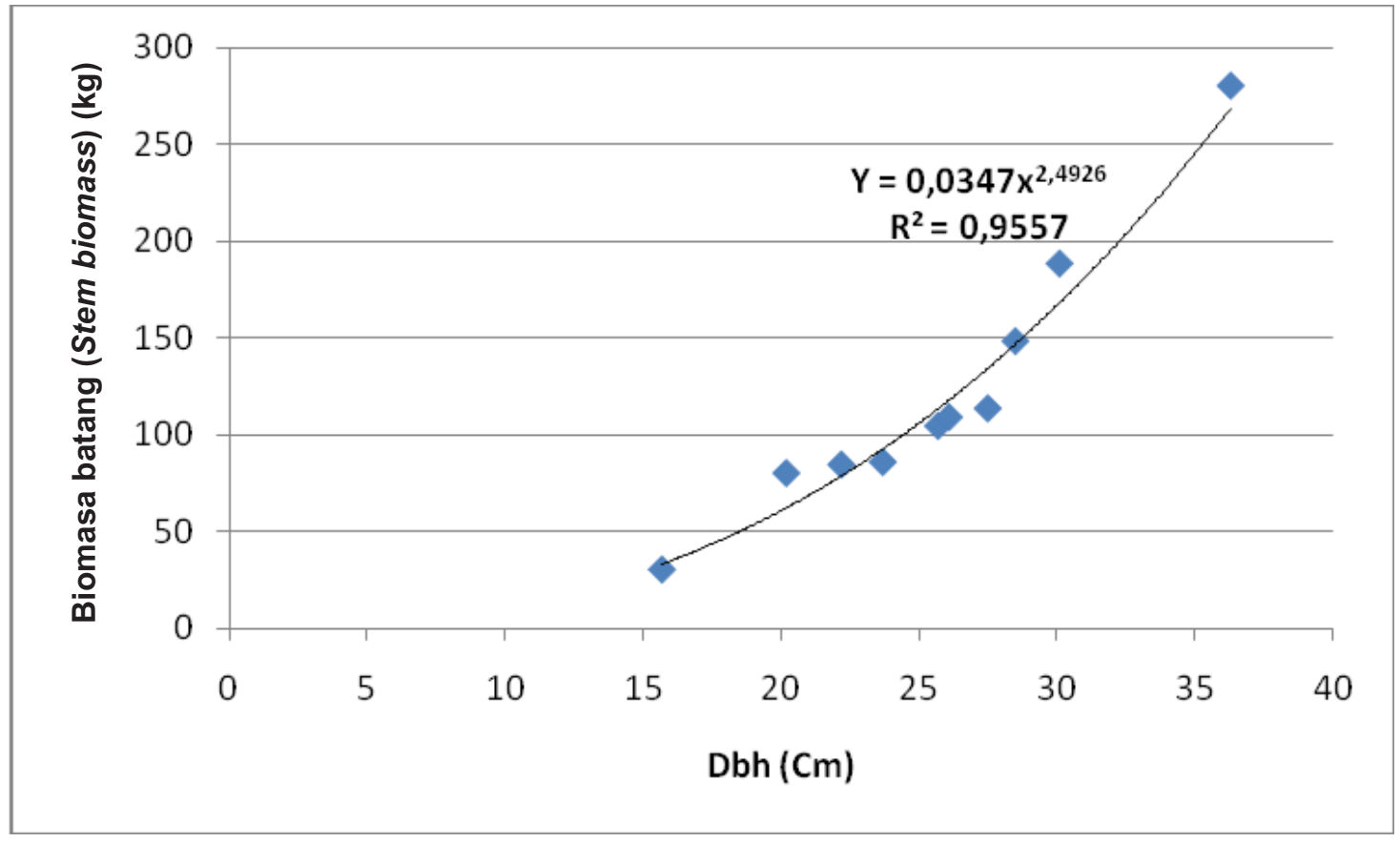

Gambar(Figure) 2. Grafik hubungan antara biomassa batang kayu afrika dengan diameter beserta persamaan alometrinya (Allometric equation of the relationship between stem dry weight and diameter at breast height) 


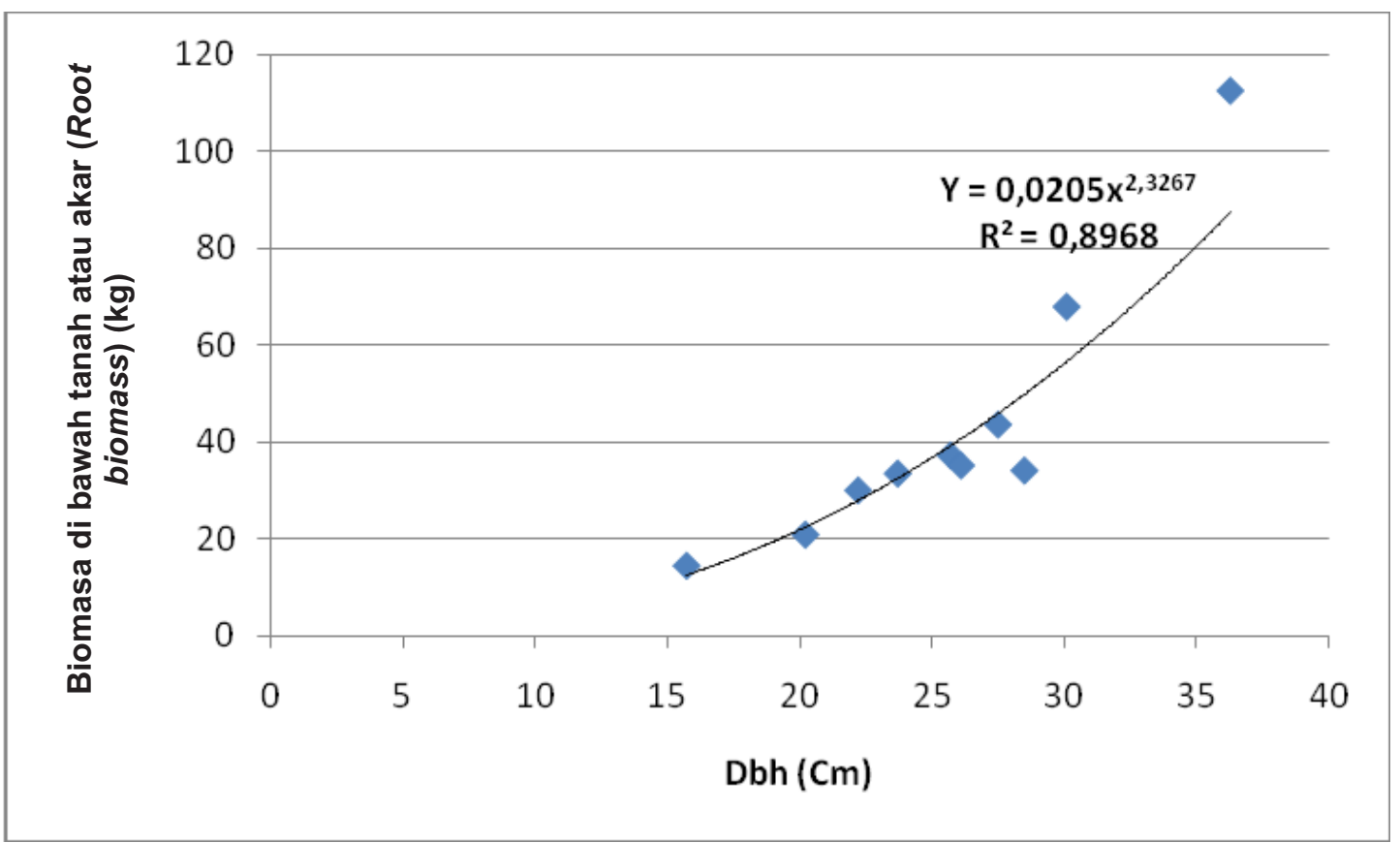

Gambar(Figure) 3. Grafik hubungan antara berat kering akar kayu afrika dengan diameter beserta persamaan alometrinya (Allometric equation of the relationship between root dry weight and diameter at breast height)

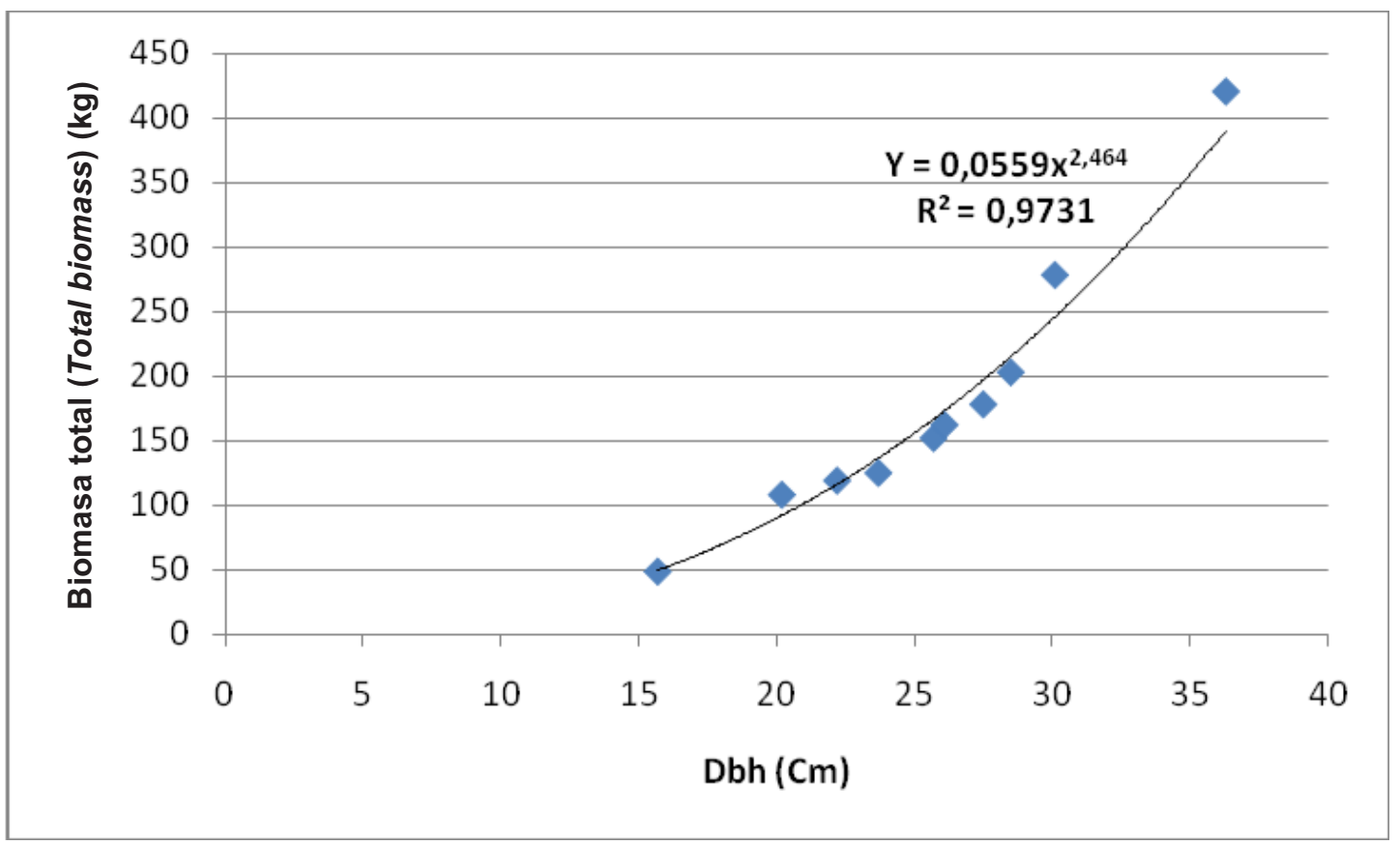

Gambar(Figure) 4. Grafik hubungan antara biomassa total kayu afrika dengan diameter beserta persamaan alometrinya (Allometric equation of the relationship between total dry weight and diameter at breast heigh) 
Gambar 1, 2, 3 dan 4, antara biomassa pada tiap bagian tegakan kayu afrika (akar, batang, bagian di atas tanah dan total) dengan diameter memiliki korelasi yang tinggi. Nilai koefisien determinasi $\left(\mathrm{R}^{2}\right)$ untuk semua hubungan didapatkan di atas $90 \%$, yang berarti $90 \%$ keragaman dari biomassa kayu afrika dapat dijelaskan oleh persamaan tersebut. Nilai simpangan agregat $(\mathrm{Sa})=1,01 \%$ dan simpangan rata-rata $(\mathrm{Sr})=7,82 \%$, berdasar-kan nilai tersebut persamaan dapat dikatakan valid atau dapat dipercaya. Dengan demikian untuk menduga biomassa kayu afrika dapat dilakukan dengan cara mengukur diameter saja.

\section{Kandungan karbon dan konbondioksida tegakan kayu afrika}

Pada penelitian ini semua pohon kayu afrika diukur tinggi dan diameternya secara sensus, luas lahan 1 ha dengan jumlah pohon 450 (kerapatan tegakan 450 pohon per ha), data kelas diameter tersebut disajikan pada Gambar 5. Pada Gambar 5 tersebut, sebaran tegakan kayu afrika umur delapan tahun didominir oleh kelas diameter 20 $\mathrm{cm}-30 \mathrm{~cm}$ dan grafiknya berbentuk lonceng (tegakan normal).

Hairiah \& Rahayu (2007), yang menyatakan bahwa rata-rata $46 \%$ kandungan karbon pada tanaman kayu afrika bahan kering pohon terdiri dari kandungan karbon. Kandungan karbon dan karbondioksida pada tegakan kayu afrika umur 8 tahun, berdasarkan rumus hubungan biomassa total dengan diameter yakni persamaan $\mathrm{Y}=$ $0,0559 \mathrm{x}^{2,464}$ tegakan kayu afrika tersebut tersaji pada Tabel 3, demikian juga dengan biomassa bagian pohon (batang, akar, cabang dan ranting serta daun).

Tabel 3 di atas dapat dikatakan bahwa biomassa pada tegakan kayu afrika umur 8 tahun sebesar 66,63 to per ha. Kandungan karbonnya sebesar 30,65 ton $\mathrm{C}$ per ha dan kandungan karbondioksida sebesar 112,39 ton $\mathrm{CO}_{2}$ per ha. Bagian batang pohon merupakan bagian tertinggi kandungan karbonnya, akar, cabang ranting dan bagian daun. Kandungan karbon pada penelitian ini termasuk tinggi bila dibandingkan dengan hasil penelitian Heriyanto \& Siregar (2007a; 2007b), pada tegakan tusam (Pinus merkusii Jungh et de Vriese) umur 5 tahun di Cianten, Bogor dilaporkan bahwa kandungan karbon dan serapan $\mathrm{CO}_{2}$ sebanyak 11,93 ton $\mathrm{C}$ per ha atau setara dengan 43,74 ton $\mathrm{CO}_{2}$ per ha. Pada akasia (Acacia mangium Willd,), umur 5 tahun di Parung Panjang, Bogor, kandungan karbonnya sebesar 31,41 ton $\mathrm{C}$ per ha atau setara dengan 115,29 ton $\mathrm{CO}_{2}$ per ha. Onrizal et al. (2010), melaporkan kandungan karbon Eucalyptus

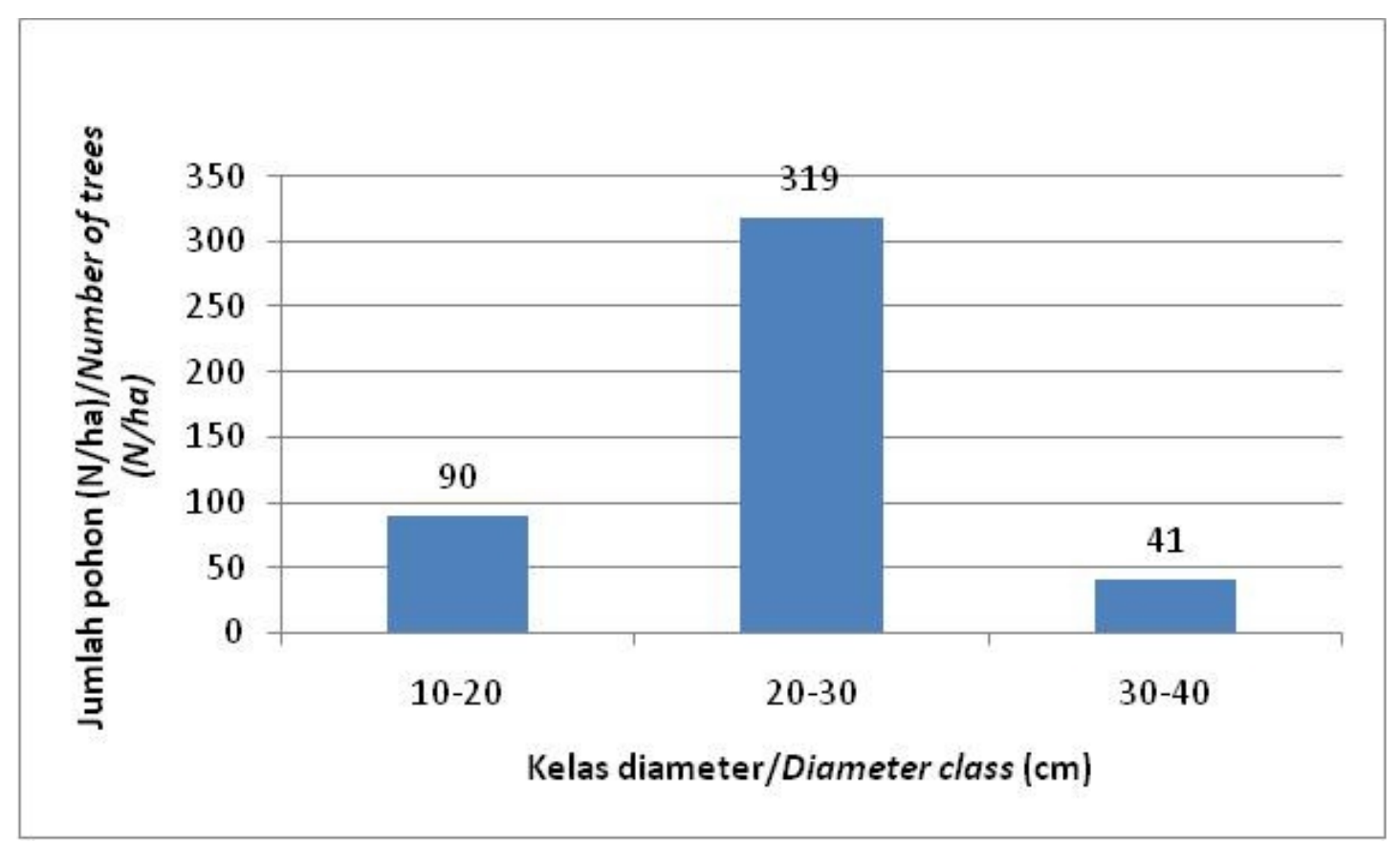

Gambar(Figure) 4. Grafik hubungan antara biomassa total kayu afrika dengan diameter beserta persamaan alometrinya (Allometric equation of the relationship between total dry weight and diameter at breast heigh) 
Tabel (Table) 3. Biomassa, karbon dan karbondioksida tegakan Maesopsis emenii umur 8 tahun(Biomass, carbon and carbondioxide Maesopsis emenii stand 8 year old) per ha

\begin{tabular}{|c|c|c|c|c|c|c|c|c|}
\hline $\begin{array}{c}\text { Kelas } \\
\text { Diameter } \\
\text { (Diameter } \\
\text { class })(\mathrm{cm})\end{array}$ & $\begin{array}{c}\text { Kerapatan } \\
\text { tegakan } \\
\text { (Stand } \\
\text { density) } \\
\text { (trees) } \\
\text { per ha }\end{array}$ & $\begin{array}{c}\text { Biomassa } \\
\text { batang } \\
\text { (Stem } \\
\text { biomass) } \\
\text { (ton per ha) }\end{array}$ & $\begin{array}{c}\text { Biomassa } \\
\text { akar (Root } \\
\text { biomass) } \\
\text { (ton per ha) }\end{array}$ & $\begin{array}{c}\text { Biomassa } \\
\text { daun (Leaf } \\
\text { biomass) } \\
\text { (ton per ha) }\end{array}$ & $\begin{array}{c}\text { Biomassa } \\
\text { cabang \& } \\
\text { ranting } \\
\text { (Branch and } \\
\text { twig biomass) } \\
\text { (ton per ha) }\end{array}$ & $\begin{array}{l}\text { Biomassa } \\
\text { pohon } \\
\text { (Biomass) } \\
\text { (ton per } \\
\text { ha) }\end{array}$ & $\begin{array}{c}\text { Karbon } \\
\text { (Carbon) } \\
\text { (ton C per } \\
\text { ha) }\end{array}$ & $\begin{array}{l}\text { Karbon } \\
\text { dioksida } \\
\text { (Carbondi } \\
\text { oxide) } \\
\text { (ton CO2 } \\
\text { per ha) }\end{array}$ \\
\hline $10-20$ & 90 & 4,06 & 1,44 & 0,21 & 0,24 & 5,95 & 2,74 & 10,03 \\
\hline $20-30$ & 319 & 33,14 & 11,60 & 1,64 & 2,29 & 48,67 & 22,39 & 82,08 \\
\hline $30-40$ & 41 & 8,18 & 2,87 & 0,41 & 0,56 & 12,02 & 5,53 & 20,27 \\
\hline Total & 450 & 45,48 & 15,91 & 2,26 & 3,09 & 66,63 & 30,65 & 112,39 \\
\hline
\end{tabular}

grandis umur 9 tahun di Sumatera Utara sebesar 58,43 ton $\mathrm{C}$ per ha. Hal ini menunjukkan bahwa kandungan karbon dipengaruhi oleh umur dan jenis pohon. Pada pohon yang cepat tumbuh cepat akan menghasilkan kandungan karbon yang tinggi dan sifat pohon yang demikian dapat dijadikan alternatif untuk menghijaukan tanahtanah yang kritis.

\section{KESIMPULAN DAN SARAN}

\section{A. Kesimpulan}

Persamaan alometri biomassa bagian atas tanah kayu afrika (batang, cabang, ranting, daun dan buah) dengan variabel penduga diameter setinggi dada $\left(\mathrm{Y}_{\text {-atastanah }}\right)=0,0363 \mathrm{x}^{2,5131}\left(\mathrm{R}^{2}=0,96\right)$, biomassa batang $\left(\mathrm{Y}_{\text {-batang }}\right)=0,0347 \mathrm{x}^{2,4926}\left(\mathrm{R}^{2}=\right.$ $0,95)$, biomassa akar $\left(\mathrm{Y}_{\text {-akar }}\right)=0,0205 \mathrm{x}^{2,3267}\left(\mathrm{R}^{2}=\right.$ $0,90)$ dan biomassa total $\left(\mathrm{Y}_{\text {-total }}\right)=0,0559 \mathrm{x}^{2,464}\left(\mathrm{R}^{2}\right.$ $=0,97)$. Kandungan karbon rata-rata kayu afrika paling tinggi diperoleh pada bagian batang yaitu $68,07 \%$, diikuti oleh bagian akar 23,87\%, cabang dan ranting $3,97 \%$ dan bagian daun $3,35 \%$. Total kandungan karbon pada tegakan kayu afrika pada umur 8 tahun 30,65 ton $C$ per ha.

\section{B. Saran}

Persamaan alometri biomassa bagian atas tanah kayu afrika ini hanya berlaku di areal kawasan hutan Bodogol, Seksi Konservasi Wilayah II Taman Nasional Gunung Gede Pangrango, Kabupaten Sukabumi, Jawa Barat dan/atau daerah lainnya yang setipe.

\section{UCAPAN TERIMA KASIH}

Pada kesempatan ini penulis mengucapkan terima kasih kepada Kepala Seksi Konservasi
Wilayah II Taman Nasional Gunung Gede Pangrango beserta staf di Bodogol, masyarakat dan staf biometerika Pusat Penelitian dan Pengembangan Hutan yang telah membantu dalam pelaksanaan penelitian ini.

\section{DAFTAR PUSTAKA}

Ani, S., \& Aminah, H. (2006). Plantation timber of Maesopsis eminii, Journal of Tropical Forest Science, 18(2), 87-90.

Bintoro, A.O., \& Riniarti, M. (2014). Pengaruh perendaman benih pada berbagai suhu air terhadap viabilitas benih kayu afrika (Maesopsis eminii). Jurnal Sylva Lestari, 2(1), 101-108.

Bismark, M., Subiandono, E, \& Heriyanto, N.M. (2008). Keragaman dan potensi jenis serta kandungan karbon hutan mangrove di sungai subelen Siberut. Jurnal Penelitian Hutan dan Konservasi Alam, 5(3), 297-306.

Dharmawan, I. W. S. \& Siregar, C. A. (2008). Karbon tanah dan pendugaan karbon tegakan Avicennia marina (Forsk.) Vierh. di BKPH Ciasem, Purwakarta. Jurnal Penelitian Hutan dan Konservasi Alam, 5(4), 317-328.

Dharmawan, I. W. S. \& Samsoedin, I. (2012). Dinamika potensi biomassa karbon pada landskap hutan bekas tebangan di Hutan Penelitian Malinau. Jurnal Penelitian Sosial dan Ekonomi Kehutanan, 9(1), 12-20.

Hairiah, K., \& Rahayu, S. (2007). Pengukuran karbon tersimpan di berbagai macam penggunaan lahan. World Agroforestry Centre. ICRAFSA, Bogor.

Heriansyah, I., Miyakuni, K., Kato,T., Kiyono, Y., \& Kanazawa, Y. (2007). Crowth characteristics and biomass accumulations of Acacia mangium under different management practices in Indonesia. Journal of Tropical Forest Science, 19(4), 226-235 
Heriyanto, N.M., \& Siregar, C.A. (2007a). Biomassa dan kandungan karbon pada hutan tanaman tusam (Pinus merkusii Jungh et de Vriese) umur lima tahun di Cianten Bogor. Jurnal Penelitian Hutan dan Konservasi Alam, 4(1), 75-81.

Heriyanto, N.M., \& Siregar, C.A. (2007b). Biomassa dan konservasi karbon pada hutan tanaman mangium (Acacia mangium Willd,) di Parungpanjang, Bogor. Jawa Barat. Info Hutan. Pusat Litbang Hutan dan Konservasi Alam, 4(1), 6573.

Onrizal \& Kusmana, C. (2009). Struktur dan keanekaragaman jenis mangrove pasca tsunami di Pulau Nias. Jurnal Berita Biologi, 9(4), 359364.

Onrizal, Ismail, E.A., Perbatakusuma, H., Sudjito, J., Suprijatna, \& Wijayanto, I.H. (2008). Struktur vegetasi dan simpanan karbon hutan hujan primer di Batang Toru, Sumatera Utara. Jurnal Biologi Indonesia, 5(2), 187-199.
Onrizal, Hartono, R., Basuki, R.B., \& Kusmana, C. (2010). Simpanan karbon biomassa hutan tanaman Eucalyptus grandis di Sumatera Utara. Cadangan karbon pada berbagai tipe hutan dan jenis tanaman di Indonesia. Pusat Penelitian dan Pengembangan Perubahan Iklim dan Kebijakan. Badan Litbang Kehutanan, Kementerian Kehutanan. Bogor. $43 \mathrm{~h}$.

Pratiwi, Narendra, B.H., Hartoyo, G.M.E., Kalima, T., \& Pradjadinata, S. (2014). Atlas Jenis-jenis Pohon Andalan Setempat untuk Rehabilitasi Hutan dan Lahan di Indonesia. Forda Press.

Samsoedin, I., Heriyanto, N.M. \& Siregar, C.A. (2009). Biomassa karbon pada Daerah Aliran Sungai (DAS) Batang Toru, Sumatera Utara. Info Hutan, 6(2), 111-124.

Subiandono, E., Bismark, M., \& Heriyanto, N.M. (2013). Kemampuan Avicennia marina (Forsk.) Vierh. dan Rhizophora apiculata Bl. dalam penyerapan polutan logam berat. Jurnal Penelitian Hutan dan Konservasi Alam, 9(1), 23-32. 